\title{
Acute malnutrition among children aged 6-59 months of the nomadic population in Hadaleala district, Afar region, northeast Ethiopia
}

\author{
Zemichael Gizaw ${ }^{1 *}$, Wondwoson Woldu² and Bikes Destaw Bitew ${ }^{1}$
}

\begin{abstract}
Background: Acute malnutrition to be a major health burden in the world, particularly in the developing world. Acute malnutrition is associated with more than one third of the global disease burden for children. Malnourished children are physically, emotionally and intellectually less productive and suffer more from chronic illnesses and disabilities. The nature, magnitude and determinants of acute malnutrition are determined among the general populations; however, there is a lack of evidence in the nomadic communities.
\end{abstract}

Methods: A cross-sectional study was conducted to assess the magnitude and factors associated with acute malnutrition among children aged 6-59 months in Hadaleala district, Afar Region. A total of 591 under-five children were included in this study, and subjects were recruited by the multistage cluster sampling technique. Data were collected by a pre-tested questionnaire and a simple anthropometric index so called mid-upper arm circumference (MUAC). The multivariable binary logistic regression analysis was used to identify factors associated with acute malnutrition on the basis of adjusted odds ratio (AOR) with 95\% confidence interval $(\mathrm{Cl})$ and $p<0.05$.

Results: The prevalence of acute malnutrition was $11.8 \%(95 \% \mathrm{Cl}=9.3,14.8 \%)$. The highest prevalence (50\%) of acute malnutrition occurred among children aged between 12.0-23.0 months. Childhood acute malnutrition was associated with the presence of two $(A O R=2.49, p<0.05)$ and three $(A O R=12.87, p<0.001)$ children in each household, unprotected drinking water sources $(A O R=3.78, p<0.05)$, absence of the latrine $(A O R=5.24, p<0.05)$, hand washing with soap ( $A O R=0.21, p<0.05)$, childhood diarrheal disease $(A O R=2.72, p<0.05)$, and child vaccination $(\mathrm{AOR}=0.15, p<0.001)$.

Conclusion: The prevalence of acute malnutrition among children aged 6-59 months was was higher than the national prevalence. The number of children in each household, drinking water sources, latrine availability, hand washing practice before food preparation and child feeding, childhood diarrheal disease, and child vaccination were identified as factors affecting the childhood acute malnutrition in the nomadic community. Protecting drinking water sources from possible contaminants, improving hand washing practices, utilization of latrine, preventing diarrheal diseases and vaccinating children integrated with the access of nutrition education is important to improve nutrition of children of the nomadic people.

Keywords: Acute malnutrition, Children aged 6-59 months, Nomads, Afar region, Ethiopia

\footnotetext{
* Correspondence: zemichael12@gmail.com

'Department of Environmental and Occupational Health and Safety,

University of Gondar, Gondar, Ethiopia

Full list of author information is available at the end of the article
} 


\section{Background}

Under nutrition continues to be a major health burden in the world, particularly in the developing world [1-3]. Globally, children with moderate and severe acute under nutrition are approximately 60 million and 13 million respectively $[1,2]$. Under nutrition is globally the most important risk factor for illness and death, with hundreds of millions of young children particularly affected $[4,5]$. It is associated with more than one third of the global disease burden for children [6]. Between 8 to 11 million under-five children die each year globally $[2,7]$, and more than $35 \%$ of these deaths are attributed to under nutrition [3].

Under nutrition among children is a critical problem. Its effects are long lasting [1, 8]. Under nourished children are physically, emotionally and intellectually less productive and suffer more from chronic illnesses and disabilities [9-12]. Malnutrition affects child performance, health, and survival $[13,14]$. In the long term, early nutritional deficits are linked to impairments of intellectual performance; work capacity, reproductive outcomes and overall health during adolescence and adulthood [14-18]. The immediate consequences of poor nutrition during the early years include significant morbidity and mortality and delayed mental and motor developments. Malnutrition at the early stages of life can lower child resistance to infections [19]. Moreover, the potential negative impact of child malnutrition goes beyond the individual, affecting society and future generations [20,21].

In Ethiopia, under nutrition among children is still a common problem. Ethiopia is one of the countries with very high burden of under nutrition. In the country, under nutrition is the underlying cause of $57 \%$ of child deaths [22-25].

Under nutrition among children depends on complex interactions of various factors, like socio-demographic [24-30], drinking water quality [26, 28, 29, 31-35], hygiene of complementary foods [24, 28], environmental sanitation [26, 31, 32, 36-38], child co-morbidities [19, 39-44], and child vaccination [45-47]. Though, the nature, magnitude and determinants of under nutrition are determined among the general populations, there is lack of evidence in the nomadic communities. This cross-sectional study was therefore conducted to assess the magnitude and factors associated with acute malnutrition among children aged 6-59 months in Hadaleala district, Afar Region, northeast Ethiopia.

\section{Methods}

\section{Study design and settings}

A community - based cross-sectional study was conducted among the nomadic populations in Hadaleala district, Afar Region, northeast Ethiopia in May, 2015. Hadaleala district is located at $341 \mathrm{~km}$ southwest of the regional capital, Semera, and $268 \mathrm{~km}$ north of Addis
Ababa, the capital city of Ethiopia. It has an area of $1272 \mathrm{~km}^{2}$ divided into 11 rural kebeles (the smallest administrative units in Ethiopia) with a total population of 42,845 as projected for the year 2015 . It has 7516 households with an average household size of 5.7 persons per house. Under-five children account for 10.1\% (4328) of the total population. As the population lives in a very scattered manner, the average population density is 14 persons $/ \mathrm{km}^{2}$. Furthermore, the economy of the district is based on livestock and crop production [48].

\section{Sample size determination}

The sample size was determined using the single population proportion formula by considering the following assumptions: $p=10.0 \%$ (prevalence of malnutrition among children aged 6-59 months in Bule Hora district, South Ethiopia [49]), 95\% confidence interval, and a $4 \%$ margin of error (d),

$$
n=\frac{\left(z_{\alpha / 2}\right)^{2} p(1-p)}{d^{2}}=\frac{(1.96)^{2} 0.1(1-0.1)}{0.04^{2}}=217
$$

Considering the design effect of 2 and 10\% non response rate, the final sample size was 478 mother-child pair.

\section{Sampling procedure}

The multistage cluster sampling technique was used to select study participants from the nomadic population. The clusters were villages with defined geographical boundaries. Out of a total of 11 kebeles, 6 were selected by the simple random sampling technique. The 6 selected kebeles were clustered into 39 villages, and 17 villages were selected by the systematic random sampling technique. All the households (591) found in the selected 17 villages with children aged 6-59 months were included in the study. For households which had more than one child each, the younger one was selected for the study.

\section{Data collection tools and procedures}

A structured questionnaire and anthropometric measurement were used to collect data. The questionnaire was pre-tested out of the study area in a community which had similar characteristics prior to the actual data collection. Eight diploma graduate nurses and two environmental health officers who were fluent enough in both Amharic and Afarigna (local languages) and working in the district were involved in the data collection process. Training was given for the data collectors and supervisors. The data collectors visited all households in the selected clusters. When the data collectors found the target groups during the visits, they interviewed the mothers about the variables and measured the circumference of the upper arm of the child. Finally, the collected data were checked and corrected by the data collectors immediately after finalizing the questionnaire. 
Supervisors daily checked the completeness, quality, and consistency of information collected.

\section{Measurement of outcome variable}

Childhood malnutrition, the primary outcome variable of this study, is determined by a simple anthropometric index the so called mid-upper arm circumference (MUAC). Nutritional status of children was take as acute malnutrition if MUAC value is lower than $125 \mathrm{~mm}$ [50].

Childhood diarrheal disease, one of the predictor variables is defined as having three or more loose or watery stools in $24 \mathrm{~h}$ [51, 52]. Household economic status, which was the other predictor variable was calculated by using tropical livestock unit (TLU). Tropical livestock unit was determined by multiplying the number of specific species with the TLU conversion factor assigned to that specific species. Camels, cattle, sheep, goats, horses, mules, asses, and chickens were common in the study area. Generally, TLU was determined as (1.0* Number of camels $)+(0.8 *$ Number of horses $)+(0.7 *$ Number of mules $)+(0.7 *$ Number of cattle $)+(0.5 *$ Number of asses $)$ $+(0.1 *$ Number of sheep $)+(0.1 *$ Number of goats $)$ $+(0.01 *$ Number of chickens). Household economic status was determined by comparing the TLU scores with the standard score. A below 5 TLU score indicated that the household was poor. A TLU score of 5 to 12.99 showed the household was medium in economic status, and rich households scored 13 and above TLU [53].

\section{Data management and statistical analysis}

Data were entered using the EPI-INFO version 3.5 .3 statistical package and exported to SPSS version 20 for further analysis. Cross tabulation was used to describe socioeconomic, environmental sanitation, health, and nutritional characteristics of children. Categorical data were presented as frequency counts or percentages and compared using the Pearson chi-square. Continuous data were summarized as mean or median with \pm standard deviation and interquartile range. The univariable binary logistic regression analysis was used to choose variables for the multivariable binary logistic regression analysis, and variables which had less than $0.2 \mathrm{p}$ - values by the univariable analysis were then analyzed by the multivariable binary logistic regression for controlling the possible effects of confounders, and finally, variables which had significant association were identified on the basis of adjusted odds ratio (AOR) with $95 \% \mathrm{CI}$ and $p<0.05$.

\section{Results}

\section{Socio-demographic information}

A total of 591 mothers - child pair participated in this study with a $100 \%$ response rate. More than half, 311 $(52.6 \%)$ of the mothers were aged $25-34$ years. The median age of the mothers was 30 years, and the interquartile range was $25-35$ years. Almost all, 577 $(97.6 \%)$ of the mothers were married at the time of data collection. The great majority, $514(87.0 \%)$ of mothers were illiterate. Almost all, 559 (94.6\%) of the mothers were housewives by occupation. Five hundred thirty seven (90.9\%) mothers were Afar by ethnicity. More than half, 339 (57.4\%) of the households had more than five family members. Three hundred eighty - two (64.6\%) households were economically poor. Two hundred twenty - nine $(38.7 \%)$ of the children were aged above 35 months. The median age of children was 28 months and the interquartile range (IQR) was 1640 months. More than half, 338 (57.2\%) of the households had only one child aged 6-59 months, and 317 $(53.6 \%)$ of the children were male (Table 1$)$.

\section{Drinking water and hygiene of complementary foods}

Three hundred fifty - four (59.9\%) households collected drinking water from unimproved sources and the greater majority, $522(88.3 \%)$ of the water sources were seasonal. Very few, 20 (3.4\%) households treated drinking water at home. Cow or goat milk was the commonest, 337 (57.0\%) complementary food for the children. Three hundred thirty - three (56.3\%) households served uncooked foods for the children, and the greater majority, $551(93.2 \%)$ of the households used unclean utensils to serve foods. Three - forth, 447 (75.6\%) of the households fed the children soon after the food is prepared, and the overwhelming majority, 539 (91.2\%) used leftover foods. Three hundred twenty - four (54.8\%) mothers washed hands with only water (Table 2 ).

\section{Personal hygiene and environmental sanitation}

Nearly one - tenth, 56 (9.5\%) of the mothers had good personal hygiene. More than threefold, 483 (81.7\%), and $490(82.9 \%)$ of the households practiced open defecation and indiscriminate solid waste disposal respectively. The living environment of 464 (78.5\%) households was poor condition, and vector infestation was observed among 483 (81.7\%) households. Three hundred thirty (55.8\%) households had only one room, and very few, 91 (15.4\%) households had cemented or plastered floor (Table 3).

\section{Health condition of mothers and children}

Sixty (10.2\%) mothers and 172 (29.1\%) children had diarrheal disease in the 2 week period prior to the survey. A majority, 416 (70.4\%) of the mothers didn't know the causes of diarrhea. Three hundred twenty - seven (55.3\%) and 377 (63.8\%) mothers didn't know that flies and child excreta can cause diarrheal diseases, respectively. The great majority, 477 (80.7\%) of the children had ever been vaccinated. However, significant number or proportion, $254(43.0 \%)$ and $418(70.7 \%)$ of the children had no measles and rotavirus vaccination respectively. 
Table 1 Socioeconomic information of households $(n=591)$ in Hadaleala district, Afar region, northeast Ethiopia, April to May, 2015

\begin{tabular}{|c|c|c|}
\hline Variables & Frequency & Percentage \\
\hline \multicolumn{3}{|l|}{ Age of mothers in years } \\
\hline $15-24$ & 131 & 22.2 \\
\hline $25-34$ & 311 & 52.6 \\
\hline$\geq 35$ & 149 & 25.2 \\
\hline \multicolumn{3}{|l|}{ Marital status of mothers } \\
\hline Currently married & 577 & 97.6 \\
\hline Currently not married & 14 & 2.4 \\
\hline \multicolumn{3}{|c|}{ Educational level of mothers } \\
\hline No formal education & 514 & 87.0 \\
\hline Formal education & 77 & 13.0 \\
\hline \multicolumn{3}{|c|}{ Occupational status of mothers } \\
\hline Housewife & 559 & 94.6 \\
\hline Employed & 32 & 5.4 \\
\hline \multicolumn{3}{|l|}{ Ethnic group of mothers } \\
\hline Afar & 537 & 90.9 \\
\hline Oromo & 44 & 7.4 \\
\hline Amhara & 10 & 1.7 \\
\hline \multicolumn{3}{|l|}{ Family size } \\
\hline$\leq 5$ & 252 & 42.6 \\
\hline$>5$ & 339 & 57.4 \\
\hline \multicolumn{3}{|c|}{ Household economic status } \\
\hline Poor & 382 & 64.6 \\
\hline Medium & 209 & 35.4 \\
\hline \multicolumn{3}{|l|}{ Age group of children } \\
\hline $6.0-11.0$ & 72 & 12.2 \\
\hline $12.0-23.0$ & 152 & 25.7 \\
\hline $24.0-35.0$ & 138 & 23.4 \\
\hline$>35.0$ & 229 & 38.7 \\
\hline \multicolumn{3}{|l|}{ Sex of children } \\
\hline Male & 317 & 53.6 \\
\hline Female & 274 & 46.4 \\
\hline \multicolumn{3}{|l|}{ Number of children } \\
\hline One & 338 & 57.2 \\
\hline Two & 218 & 36.9 \\
\hline Three & 35 & 5.9 \\
\hline
\end{tabular}

Four hundred eighty- eight (82.6\%) of the children received vitamin A supplementation (Table 4).

\section{Nutritional status}

The MUAC value of 70 children was below $125 \mathrm{~mm}$. Therefore, the prevalence of acute malnutrition among children aged 6 - 59 months in the nomadic population of Hadaleala district, Afar Region was found to be $11.8 \%$
Table 2 Drinking water and hygiene of complementary foods of households in Hadaleala district, Afar region, northeast Ethiopia, April to May, 2015

\begin{tabular}{|c|c|c|}
\hline Environmental variables & Frequency & Percentage \\
\hline \multicolumn{3}{|l|}{ Drinking water sources } \\
\hline Improved & 237 & 40.1 \\
\hline Unimproved & 354 & 59.9 \\
\hline \multicolumn{3}{|l|}{ Seasonality of water sources } \\
\hline Permanent & 69 & 11.7 \\
\hline Temporarily & 522 & 88.3 \\
\hline \multicolumn{3}{|l|}{ Home based water treatment } \\
\hline Yes & 20 & 3.4 \\
\hline No & 571 & 96.6 \\
\hline \multicolumn{3}{|c|}{ Types of complementary foods for the children } \\
\hline Cow or goat milk & 337 & 57.0 \\
\hline Adults' food & 133 & 22.5 \\
\hline Gruel & 112 & 19.0 \\
\hline Infant formula/Powder milk & 9 & 1.5 \\
\hline \multicolumn{3}{|c|}{ Using unclean utensils to serve foods } \\
\hline Yes & 551 & 93.2 \\
\hline No & 40 & 6.8 \\
\hline \multicolumn{3}{|c|}{ Serving uncooked food for the children } \\
\hline Yes & 333 & 56.3 \\
\hline No & 258 & 43.7 \\
\hline \multicolumn{3}{|c|}{ Feeding children soon after food prepared } \\
\hline Yes & 447 & 75.6 \\
\hline No & 144 & 24.4 \\
\hline \multicolumn{3}{|l|}{ Children ate leftover foods } \\
\hline Yes & 539 & 91.2 \\
\hline No & 52 & 8.8 \\
\hline \multicolumn{3}{|l|}{ How do you wash your hand } \\
\hline With plain water & 324 & 54.8 \\
\hline With soap & 267 & 45.2 \\
\hline
\end{tabular}

(95\% CI $=9.3,14.8 \%)$. Female children were more malnourished than males. Out of 70 malnourished children, $42(60 \%)$ females and 28 (40\%) males were malnourished respectively. The highest prevalence of acute malnutrition occurred among children aged 12-23 months, which accounted 35 (50\%) (Fig. 1).

\section{Factors associated with nutritional status}

Table 5 presents the results of the binary logistic regression analysis on socioeconomic, water and hygiene of complementary foods, personal hygiene and environmental sanitation, and health related variables. Childhood acute malnutrition was statistically associated with the number of children in the household. 
Table 3 Personal hygiene and environmental sanitation of households in Hadaleala district, Afar region, northeast Ethiopia, April to May, 2015

\begin{tabular}{lll}
\hline Environmental variables & Frequency & Percentages \\
\hline Personal hygiene of mothers & 535 & 90.5 \\
Poor & 56 & 9.5 \\
Good & 108 & 18.3 \\
Latrine availability & 483 & 81.7 \\
Yes & & \\
No & 101 & 17.1 \\
Solid waste management & 490 & 82.9 \\
Controlled & & \\
Open field & 464 & 78.5 \\
Environmental sanitation & 127 & 21.5 \\
Poor & & 81.7 \\
Good & 483 & 18.3 \\
Infestation of insects & 108 & \\
Yes & & 5.6 \\
No & 330 & 39.8 \\
Number of rooms & 231 & 5.1 \\
One & 30 & \\
Two & 500 & \\
Three & 91 & \\
Eousing floor material & & \\
Cemented & & \\
\hline
\end{tabular}

Acute malnutrition was 2.49 times more likely to be higher among households with two children compared with households with only one child $[\mathrm{AOR}=2.49,95 \% \mathrm{CI}$ $=(1.06,5.85)]$. Similarly, the likelihood of acute malnutrition was also 12.87 times higher among households with three children compared with households who had one child $[$ AOR $=12.87,95 \% \mathrm{CI}=(4.04,41.00)]$.

Acute malnutrition among children aged 6 - 59 months was associated with drinking water sources, availability of latrine, and hand washing practices. It was 3.78 times more likely to be higher among households that collected drinking water from unprotected sources $[\mathrm{AOR}=3.78$, $95 \% \mathrm{CI}=(1.07,13.34)]$. The likelihood of childhood acute malnutrition was 5.24 times to be higher among households who had no latrine compared with their counterparts $[\mathrm{AOR}=5.24,95 \% \mathrm{CI}=(1.19,23.19)]$. Children whose mothers washed their hands before food preparation and feeding with soap were less likely to be malnourished. Hand washing with soap before food preparation and child feeding can prevent childhood acute malnutrition by $79 \%[\mathrm{AOR}=0.21,95 \% \mathrm{CI}=(0.05,0.81)]$.

Childhood acute malnutrition was also statistically associated with the health status of children, like childhood
Table 4 Health conditions of mothers and children in Hadaleala district, Afar region, northeast Ethiopia, April to May, 2015

\begin{tabular}{|c|c|c|}
\hline Health related information & Frequency & Percentage \\
\hline \multicolumn{3}{|c|}{ Two week history of maternal diarrhea } \\
\hline Yes & 60 & 10.2 \\
\hline No & 531 & 89.8 \\
\hline \multicolumn{3}{|l|}{ Childhood diarrhea } \\
\hline Yes & 172 & 29.1 \\
\hline No & 419 & 70.9 \\
\hline \multicolumn{3}{|c|}{ Mothers know the causes of diarrheal disease } \\
\hline Yes & 175 & 29.6 \\
\hline No & 416 & 70.4 \\
\hline \multicolumn{3}{|c|}{ Mothers know flies transmit diarrheal disease } \\
\hline Yes & 264 & 44.7 \\
\hline No & 327 & 55.3 \\
\hline \multicolumn{3}{|c|}{ Mothers know excreta of children can cause disease } \\
\hline Yes & 214 & 36.2 \\
\hline No & 377 & 63.8 \\
\hline \multicolumn{3}{|l|}{ Child ever been vaccinated } \\
\hline Yes & 477 & 80.7 \\
\hline No & 114 & 19.3 \\
\hline \multicolumn{3}{|l|}{ Measles vaccination } \\
\hline Yes & 337 & 57.0 \\
\hline No & 254 & 43.0 \\
\hline \multicolumn{3}{|l|}{ Rota virus vaccination } \\
\hline Yes & 173 & 29.3 \\
\hline No & 418 & 70.7 \\
\hline \multicolumn{3}{|l|}{ Vitamin A supplementation } \\
\hline Yes & 488 & 82.6 \\
\hline No & 103 & 17.4 \\
\hline
\end{tabular}

diarrhea and vaccination. Childhood acute malnutrition was 2.72 times more likely to be higher among children who had diarrheal disease $[\mathrm{AOR}=2.72,95 \% \mathrm{CI}=(1.15$, 6.40)]. This study indicated that child vaccination has a protective effect on childhood acute malnutrition. Children who ever been vaccinated were $85 \%$ less likely to be malnourished, compared with their counterparts $[\mathrm{AOR}=0.15,95 \% \mathrm{CI}=(0.07,0.31)]$.

\section{Discussion}

The prevalence of acute malnutrition among children aged 6-59 months was $11.8 \%$ (95\% $\mathrm{CI}=9.3,14.8 \%$ ). Childhood acute malnutrition was statistically associated with the number of children in each household, drinking water sources, latrine availability, hand washing practice before food preparation and child feeding, childhood diarrheal disease, and child vaccination. The prevalence 


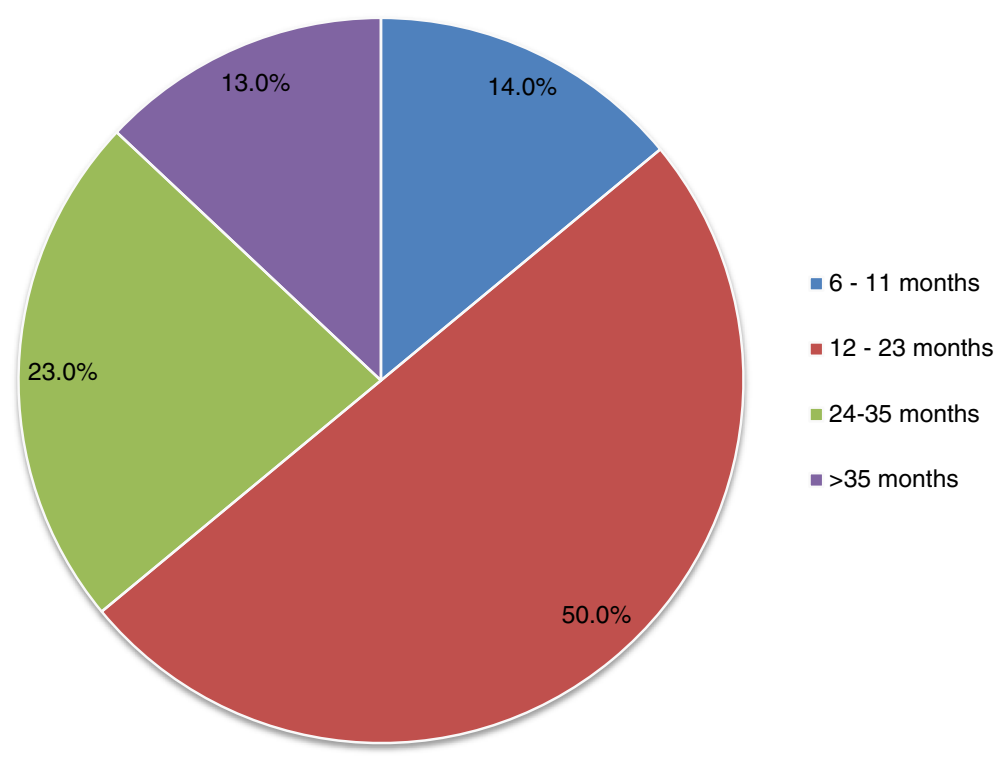

Fig. 1 Prevalence of acute malnutrition with respect to age of children in Hadaleala district, Afar region, northeast Ethiopia, April to May, 2015

of acute malnutrition reported by this study is slightly higher than the national prevalence of acute malnutrion (9\%) [54] and findings of various studies conducted in Ethiopia like Bule Hora district, South Ethiopia, 10\% [49] and it was also just two-fold higher than the prevalence reported in Aleta Chucko and Aleta Wondo districts, Sidama Zone, South Ethiopia, 5.6\% [55]. Whereas, the magnitude of acute malnutrition reported by this study was lower than the findings of studies conducted in Pagak district, South Sudan, 16.7\% [56]. The difference in prevalence might be attributed to the difference in the socio- demographic, environmental, and behavioral characteristics of households and the nomadic nature of the population.

This study showed that families who had two or above children aged 6-59 months were more likely to have childhood acute malnutrition than those who had only one child. This probably attributed to less balanced diet intake and accessibility of child healthcare decreased with more number of children per household, especially in low income families [33, 34, 57, 58].

In this study, it was found that acute malnutrition was associated with unprotected drinking water sources, open defecation, and poor hand washing practices of mothers. Different studies also reported that acute malnutrition was associated with drinking water sources $[26,28,29,31-35]$, availability of latrine $[26,31,32,36-38]$ and hand washing practices $[36,59]$. This may be so because poor water, hygiene and sanitation condition increase the risk of infections. Infections affect nutrient absorption and compromised nutritional status of children. Evidences show that children who frequently affected by infections have mal-absorption of important nutrients [60-63].

This study indicated that acute malnutrition was associated with child hood diarrheal diseases. Children who had diarrheal disease were more likely to be acutely malnourished as compared with their counter parts. This finding was supported by the findings of other similar studies [24, $28,33,36,38,64-66]$. This may be due to the fact that diarrheal disease due to poor hygiene and lack of sanitation induces a gut disorder called environmental enteropathy (EE) characterized by blunted intestinal villi, increased intestinal permeability; fat and carbohydrate mal-absorption, and increased protein needs [67] that diverts energy from growth towards an ongoing fight against subclinical infection [68-71]. EE is a major cause of postnatal stunting and wasting [71-77].

Child vaccination was also the other statistically associated variable with childhood acute malnutrition. Children who ever vaccinated were less likely to be malnourished compared with their counterparts. This finding is supported by the findings of other similar studies [36, 45-47, 78]. This can be justified as vaccinated children are less likely to be frequently infected with vaccine preventable diseases such as diarrhea and respiratory infections, which are known in depleting nutrients from the body $[45,79,80]$.

Finally, this paper determined acute malnutrition using MUAC measurement. It didn't measure weight and height to determine global malnutrition. This paper also didn't consider the effect of food security and access to diversified foods on childhood malnutrition. Moreover, the paper didn't investigate demand side issues and supply side issues of systems failures with respect to poverty 
Table 5 Factors affecting acute malnutrition among children aged between 6 and 59 months in Hadaleala district, Afar region, northeast Ethiopia, April to May, 2015

\begin{tabular}{|c|c|c|c|c|}
\hline \multirow[t]{2}{*}{ Variables } & \multicolumn{2}{|c|}{ Acute malnutrition } & \multirow[t]{2}{*}{ COR with $95 \% \mathrm{Cl}$} & \multirow[t]{2}{*}{ AOR with $95 \% \mathrm{Cl}$} \\
\hline & Yes & No & & \\
\hline \multicolumn{5}{|l|}{ Number of children } \\
\hline One & 13 & 325 & 1 & \\
\hline Two & 35 & 183 & $4.78(2.47,9.27)$ & $2.49(1.06,5.85)^{*}$ \\
\hline Three & 22 & 13 & $42.31(17.52,102.18)$ & $12.87(4.04,41.00)^{* *}$ \\
\hline \multicolumn{5}{|l|}{ Family size } \\
\hline$\leq 5$ & 37 & 215 & 1 & \\
\hline$>5$ & 33 & 306 & $0.63(0.38,1.03)$ & $1.99(0.95,4.18)$ \\
\hline \multicolumn{5}{|l|}{ Wealth status } \\
\hline Poor & 58 & 324 & $2.94(1.54,5.61)$ & $1.68(0.72,3.94)$ \\
\hline Medium & 12 & 197 & 1 & \\
\hline \multicolumn{5}{|l|}{ Mothers' occupation } \\
\hline House wife & 63 & 496 & $0.45(0.19,1.09)$ & $0.20(0.04,1.05)$ \\
\hline Employee & 7 & 25 & 1 & \\
\hline \multicolumn{5}{|l|}{ Water sources } \\
\hline Protected & 4 & 233 & 1 & \\
\hline Unprotected & 66 & 288 & $13.35(4.80,37.16)$ & $3.78(1.07,13.34)^{*}$ \\
\hline \multicolumn{5}{|l|}{ Latrine availability } \\
\hline Yes & 4 & 104 & 1 & \\
\hline No & 66 & 417 & $6.61(2.04,21.40)$ & $5.24(1.19,23.19)^{*}$ \\
\hline \multicolumn{5}{|l|}{ Hand washing ${ }^{* * *}$} \\
\hline With water only & 66 & 258 & 1 & \\
\hline With soap & 4 & 263 & $0.06(0.02,0.17)$ & $0.21(0.05,0.81)^{*}$ \\
\hline \multicolumn{5}{|c|}{ Children eat leftover foods } \\
\hline Yes & 61 & 478 & $0.61(0.28,1.31)$ & $0.68(0.23,2.01)$ \\
\hline No & 9 & 43 & 1 & \\
\hline \multicolumn{5}{|l|}{ Childhood diarrhea } \\
\hline No & 11 & 408 & 1 & \\
\hline Yes & 59 & 113 & $19.37(9.85,38.10)$ & $2.72(1.15,6.40)^{*}$ \\
\hline \multicolumn{5}{|c|}{ Children ever vaccinated } \\
\hline Yes & 19 & 458 & $0.05(0.03,0.09)$ & $0.15(0.07,0.31)^{* *}$ \\
\hline No & 51 & 63 & 1 & \\
\hline \multicolumn{5}{|c|}{ Solid waste management } \\
\hline Controlled & 15 & 62 & $2.02(1.08,3.79)$ & $1.89(0.62,5.75)$ \\
\hline Uncontrolled & 55 & 459 & 1 & \\
\hline
\end{tabular}

*Statistically significant at $p<0.05 \mid{ }^{* *}$ statistically significant at $p<0.001 \mid$ ***before food preparation and child feeding

alleviation. The authors believed that other studies should be conducted to fill the above identified gaps.

\section{Conclusion}

The prevalence of acute malnutrition among children aged 6-59 months was higher than the national prevalence. The number of children in each household, drinking water sources, latrine availability, hand washing practice before food preparation and child feeding, childhood diarrheal disease, and child vaccination were identified as factors affecting the childhood acute malnutrition in the nomadic community. Protecting drinking water sources from possible contaminants, improving hand washing practices, utilization of latrine, preventing diarrheal diseases and vaccinating children integrated with the access of nutrition education is important to improve nutrition of children of the nomadic people. 


\section{Abbreviations}

AOR: Adjusted Odds Ratio; Cl: Confidence Interval; COR: Crude Odds Ratio; EE: Environmental Enteropathy; IQR: Interquartile Range; Km: Kilometer; $\mathrm{Km}^{2}$ : Kilometer square; MUAC: Mid-upper arm circumference; SPSS: Statistical Package for Social Sciences; TLU: Tropical Livestock Holding

\section{Acknowledgments}

The authors are pleased to acknowledge data collectors, field supervisors, study participants, Hadaleala District Health Office, Afar Regional Health Bureau for their unreserved contributions to the success of this study. The authors would also like to extend their gratitude to Hadaleala district administrators for their facilitation.

\section{Funding}

The authors of this study didn't receive funds from any funding organization. However, University of Gondar had covered questionnaire duplication and data collection fees.

\section{Availability of data and materials}

Data will be made available upon requesting the primary author.

\section{Authors' contributions}

All the authors actively participated during conception of the research issue development of a research proposal, data collection, analysis and interpretation, and writing various parts of the research report. ZG had analyzed the data and had written the manuscript. WW had designed the study protocol and had supervised the quality of data. BDB had revised the study protocol and manuscript. All the authors read and approved the final manuscript.

\section{Ethics approval and consent to participate}

Ethical clearance was obtained from the Institutional Review Board of the University of Gondar and an official letter was submitted to the district administrators. There were no risks due to participation in this research project, and the collected data were used only for this research purpose. Verbal informed consent was obtained from the mothers. All information collected from each household was treated with complete confidentiality. During data collection, oral rehydration solution and Zinc tablets with clear instructions were given to children who had diarrhea, and advice was given to mothers to take their children to a nearby health institution for further management diarrhea and malnutrition.

\section{Consent for publication}

This manuscript does not contain any individual person's data.

\section{Competing interests}

The authors declare that they have no competing interests.

\section{Publisher's Note}

Springer Nature remains neutral with regard to jurisdictional claims in published maps and institutional affiliations.

\section{Author details}

'Department of Environmental and Occupational Health and Safety, University of Gondar, Gondar, Ethiopia. ${ }^{2}$ Hadaleala District Health Office, Hadaleala District, Afar Regional State, Ethiopia.

Received: 27 November 2017 Accepted: 16 January 2018 Published online: 07 February 2018

\section{References}

1. Glewwe P, Miguel EA. The impact of child health and nutrition on education in less developed countries. Handb Dev Econ. 2007:4:3561-606.

2. Collins S, Dent N, Binns P, Bahwere P, Sadler K, Hallam A. Management of severe acute malnutrition in children. Lancet. 2006:368(9551):1992-2000.

3. Black RE, Allen LH, Bhutta ZA, Caulfield LE, De Onis M, Ezzati M, et al. Maternal and child undernutrition: global and regional exposures and health consequences. Lancet. 2008;371(9608):243-60.

4. Müller $\mathrm{O}$, Krawinkel M. Malnutrition and health in developing countries. Can Med Assoc J. 2005;173(3):279-86.

5. Black R. Micronutrient deficiency: an underlying cause of morbidity and mortality. Bull World Health Organ. 2003;81(2):79.
6. Huq M, Dasgupta S, Khaliquzzaman M, Pandey KD, Wheeler D. Indoor air quality for poor families: new evidence from Bangladesh. World Bank Policy Research Working Paper. 2004(3393).

7. Singer PA, Ansett S, Sagoe-Moses I. What could infant and young child nutrition learn from sweatshops? BMC Public Health. 2011;11(1):276.

8. Abuya BA, Ciera J, Kimani-Murage E. Effect of mother's education on child's nutritional status in the slums of Nairobi. BMC Pediatr. 2012;12(1):1.

9. Jesmin A, Yamamoto SS, Malik AA, Haque MA. Prevalence and determinants of chronic malnutrition among preschool children: a cross-sectional study in Dhaka City, Bangladesh. J Health Popul Nutr. 2011:494-9.

10. Dewey KG, Begum K. Long-term consequences of stunting in early life. Matern Child Nutr. 2011;7(s3):5-18.

11. Kar BR, Rao SL, Chandramouli B. Cognitive development in children with chronic protein energy malnutrition. Behav Brain Funct. 2008;4(1):1.

12. Lopez-Valcarzel A. Occupational safety and health in the construction work. Afr Newsl Occup Health Safety. 2001;11(1):4-6.

13. Ghosh AK, Bhattacherjee A, Chau N. Relationships of working conditions and individual characteristics to occupational injuries: a case-control study in coal miners. J Occup Health. 2004;46(6):470-80.

14. Onis M, Dewey KG, Borghi E, Onyango AW, Blössner M, Daelmans B, et al. The World Health Organization's global target for reducing childhood stunting by 2025: rationale and proposed actions. Matern Child Nutr. 2013;9(S2):6-26.

15. Gillespie S, Haddad L, Mannar V, Menon P, Nisbett N, Maternal, et al. The politics of reducing malnutrition: building commitment and accelerating progress. Lancet. 2013:382(9891):552-69.

16. Bhutta ZA, Das JK, Rizvi A, Gaffey MF, Walker N, Horton S, et al. Evidencebased interventions for improvement of maternal and child nutrition: what can be done and at what cost? Lancet. 2013·382(9890):452-77.

17. León-Cava N, Lutter C, Ross J, Martin L. Quantifying the benefits of breastfeeding: a summary of the evidence. Pan American Health Organization, Washington DC. 2002. Available at http://www.paho.org/hq/index. php?option=com_content\&view=article\&id=5654\%3A2011-cuantificacionbeneficios-lactancia-materna-resena-evidencia-2002\&catid=3719\%3Anutritionpublications\&ltemid=4081\&lang=en. Accessed 10 May 2017.

18. Bhandari N, Mazumder S, Bahl R, Martines J, Black RE, Bhan MK, et al. An educational intervention to promote appropriate complementary feeding practices and physical growth in infants and young children in rural Haryana, India. J Nutr. 2004;134(9):2342-8.

19. Rodríguez L, Cervantes E, Ortiz R. Malnutrition and gastrointestinal and respiratory infections in children: a public health problem. Int J Environ Res Public Health. 2011;8(4):1174-205.

20. Victora CG, Adair L, Fall C, Hallal PC, Martorell R, Richter L, et al. Maternal and child undernutrition: consequences for adult health and human capital. Lancet. 2008;371(9609):340-57.

21. Grantham-McGregor S, Cheung YB, Cueto S, Glewwe P, Richter L, Strupp B, et al. Developmental potential in the first 5 years for children in developing countries. Lancet. 2007:369(9555):60-70.

22. Ethiopia demographic and health survey, 2011. Addis Ababa, Ethiopia and Calverton, Maryland, USA: Central Statistical Agency and ICF International. 2012;430. Availlable at https://dhsprogram.com/pubs/pdf/GF26/GF26.pdf. Accessed on 16 May 2016.

23. Taylor L. From food crisis to nutrition: challenges and possibilities in Ethiopia's nutrition sector'. Institute of Development Studies. 2012.

24. Teshome B, Kogi-Makau W, Getahun Z, Taye G. Magnitude and determinants of stunting in children underfive years of age in food surplus region of Ethiopia: the case of west gojam zone. Ethiop J Health Dev. 2009;23(2).

25. Sisay Z. Magnitude and factors associated with malnutrition of children under five years of age in rural Kebeles of Haramaya, Ethiopia Harar Bull Health Sci Extracts 2012(2011):4.

26. Medhin G, Hanlon C, Dewey M, Alem A, Tesfaye F, Worku B, et al. Prevalence and predictors of undernutrition among infants aged six and twelve months in Butajira, Ethiopia: the P-MaMiE birth cohort. BMC Public Health. 2010;10(1):1

27. Yimer G. Malnutrition among children in southern Ethiopia: levels and risk factors. Ethiop J Health Dev. 2000;14(3):283-92.

28. Demissie S, Worku A. Magnitude and factors associated with malnutrition in children 6-59 months of age in pastoral community of Dollo ado district, Somali region, Ethiopia. Sci J Public Health. 2013:1(4):175-83.

29. Wondafrash M, Amsalu T, Woldie M. Feeding styles of caregivers of children 6-23 months of age in Derashe special district, southern Ethiopia. BMC Public Health. 2012;12(1):1 
30. Fentaw R, Bogale A, Abebaw D. Prevalence of child malnutrition in agro-pastoral households in afar regional state of Ethiopia. Nutr Res Pract. 2013;7(2):122-31.

31. James P, Sadler K, Wondafrash M, Argaw A, Luo H, Geleta B, et al. Children with moderate acute malnutrition with no access to supplementary feeding Programmes experience high rates of deterioration and no improvement: results from a prospective cohort study in rural Ethiopia. PLoS One. 2016; 11(4):e0153530.

32. Zewdie T, Abebaw D. Determinants of child malnutrition: empirical evidence from Kombolcha District of eastern Hararghe zone, Ethiopia. Q J Int Agric. 2013;52(4):357-72.

33. Taye A, Wolde T, Seid A. Under-nutrition and related factors among children aged 6-59 months in Gida Ayana District, Oromiya region, West Ethiopia: a community based quantitative study. J Nutr Food Sci. 2016;6(5):1-12.

34. Masibo PK, Makoka D. Trends and determinants of undernutrition among young Kenyan children: Kenya demographic and health survey; 1993, 1998, 2003 and 2008-2009. Public Health Nutr. 2012; 15(09):1715-27.

35. Kavosi E, Hassanzadeh Rostami Z, Kavosi Z, Nasihatkon A, Moghadami M, Heidari M. Prevalence and determinants of under-nutrition among children under six: a cross-sectional survey in Fars province, Iran. Int J Health Policy Manag. 2014:3:71-6.

36. Ayana $A B$, Hailemariam TW, Melke AS. Determinants of acute malnutrition among children aged 6-59 months in public hospitals, Oromia region, West Ethiopia: a case-control study. BMC Nutri. 2015;1(1):1.

37. Sharghi A, Kamran A, Faridan M. Evaluating risk factors for protein-energy malnutrition in children under the age of six years: a case-control study from Iran. Int J General Med. 2011;4:607.

38. Tariku B, Mulugeta A, Tsadik M, Azene G. Prevalence and risk factors of child malnutrition in community based nutrition program implementing and nonimplementing districts from south East Amhara, Ethiopia. Open Access Library J. 2014;1(03):1.

39. Morris SS, Cogill B, Uauy R, Maternal, Group CUS. Effective international action against undernutrition: why has it proven so difficult and what can be done to accelerate progress? Lancet. 2008;371(9612):608-21.

40. Blössner M, De Onis M, Prüss-Üstün A, Campbell-Lendrum D, Corvalán C Woodward A. Quantifying the health impact at national and local levels. Geneva: WHO; 2005.

41. Arinaitwe E, Gasasira A, Verret W, Homsy J, Wanzira H, Kakuru A, et al. The association between malnutrition and the incidence of malaria among young HIV-infected and-uninfected Ugandan children: a prospective study. Malar J. 2012;11(1):1.

42. Sackey ME. Intestinal parasitic infection: prevalence, risk factors and consequences for child growth, iron status and development in rural Ecuador. 2001.

43. Hasanain F, Jamsiah M, Zaleha M, Azmi MTamil MA. Association between drinking water sources and diarrhea with malnutrition among kindergarten's children in Baghdad city, Iraq. Malays J Public Health Med. 2012;12(1):45-8.

44. Njuguna J, Muruka C. Diarrhoea and malnutrition among children in a Kenyan District: a correlational study. J Rural Tropical Public Health. 2011;10:35-8.

45. Ma'alin A, Birhanu D, Melaku S, Tolossa D, Mohammed Y, Gebremicheal K. Magnitude and factors associated with malnutrition in children 6-59 months of age in Shinille Woreda, Ethiopian Somali regional state: a crosssectional study. BMC Nutr. 2016;2(1):44.

46. Tadesse T, Kisi T, Mekonnen H. Malnutrition and its correlates among rural primary school children of Fogera District, Northwest Ethiopia. J Nutr Disord Ther. 2013;2013

47. Ahmed T, Roy S, Alam N, Hossain Ml. Determinants of undernutrition in children under 2 years of age from rural Bangladesh. Indian Pediatr. 2012;49(10):821-4.

48. Ethiopia. Hadaleala district. Finance and economic development office annual report 2014, by Dawud Haji Alisadik and others, Hadaleala : Officer of finance and economic development Afar Region, Ethiopia, 2014.

49. Asfaw M, Wondaferash M, Taha M, Dube L. Prevalence of undernutrition and associated factors among children aged between six to fifty nine months in Bule Hora district, South Ethiopia. BMC Public health. 2015;15(1):1.

50. Grellety E, Golden MH. Weight-for-height and mid-upper-arm circumference should be used independently to diagnose acute malnutrition: policy implications. BMC nutrition. 2016;2(1):10

51. UNICEF/WHO. Diarrhoea: Why children are still dying and what can be done. The United Nations Children's Fund/World Health Organization, Geneva, 2009. Available at www.unicef.org/.../Final_Diarrhoea_Report_ October_2009_final.pdf. Accessed 18 May 2016.
52. Black RE, Morris SS, Bryce J. Where and why are 10 million children dying every year? Lancet. 2003;361(9376):2226-34.

53. Jahnke HE. Livestock production systems and livestock development in tropical Africa; Livestock Population in Tropical Africa by Species in Numbers and in Tropical Livestock Units (TLU) 1979. P. 10. www. pdf.usaid. gov/pdf_docs/PNAAN484.pdf. Accessed 10 May 2016.

54. Ethiopia Mini Demographic and Health Survey. Central Statistical Agency Addis Ababa. Ethiopia. 2014;2014:1-112. https://www.unicef.org/ethiopia/ Mini_DHS_2014_Final_Report.pdf. Accessed on 17 May 2016

55. ACF International. Maize Livelihood Belt of Aleta Chucko and Aleta Wondo Woredas, Sidama Zone, SNNPR Ethiopia final report 2014. By Jennifer Holden, Action Contre La Faim (ACF): Analyst of Nutrition Causal Analysis. Available at http://www.ghadvocates.eu/wp-content/uploads/2015/08/ Nutrition-Causal-Analysis-Link-NCA-Sidama-Zone-Ethiopia-2014.pdf. Accessed on 09 May 2016.

56. NUTRITIONAL ANTHROPOMETRIC SURVEY CHILDREN UNDER 5 YEARS OLD PAGAK DISTRICT UPPER NILE (LATJOR STATE). ACF-USA.Available at https:// www.actionagainsthunger.org/sites/default/files/publications/ACF-NUTSouth-Sudan-Latjar-Pagak-2003-04-EN.pdf. Accessed on 12 May 2016.

57. Sengupta P, Philip N, Benjamin A. Epidemiological correlates of undernutrition in under-5 years children in an urban slum of Ludhiana. Health and Popul Perspect Issues. 2010;33(1):1-9.

58. Mengistu K, Alemu K, Destaw B. Prevalence of malnutrition and associated factors among children aged 6-59 months at Hidabu Abote District, North Shewa, Oromia Regional State. J Nutr Disord Ther. 2013;2013

59. Bantamen G, Belaynew W, Dube J. Assessment of factors associated with malnutrition among under five years age children at Machakel Woreda, Northwest Ethiopia: a case control study. J Nutr Food Sci. 2014:2014

60. Spears D. The nutritional value of toilets: How much international variation in heights can sanitation explain? Discussion Paper, Delhi School of Economics, Delhi, India, 2013. Available at http://riceinstitute.org/wordpress/ wp-content/uploads/downloads/2013/07/Spears-height-and-sanitation-62013.pdf. Accessed on 05 May 2016.

61. Langford R, Lunn P, Brick CP. Hand-washing, subclinical infections, and growth: A longitudinal evaluation of an intervention in Nepali slums. Am J Hum Biol. 2011;23(5):621-9.

62. Spears D. How much international variation in child height can sanitation explain? World Bank policy 10.1186/s13052-018-0457-1 research working paper. 2013(6351). Available at http://documents.worldbank.org/curated/en/ 449651468191643600/How-much-international-variation-inchild-height-cansanitation-explain. Accessed on 04 May 2016.

63. Rah JH, Cronin AA, Badgaiyan B, Aguayo VM, Coates S, Ahmed S. Household sanitation and personal hygiene practices are associated with child stunting in rural India: a cross-sectional analysis of surveys. BMJ Open. 2015;5(2):e005180.

64. Janevic T, Petrovic O, Bjelic I, Kubera A. Risk factors for childhood malnutrition in Roma settlements in Serbia. BMC Public Health. 2010;10(1):1.

65. Fekadu Y, Mesfin A, Haile D, Stoecker BJ. Factors associated with nutritional status of infants and young children in Somali Region, Ethiopia: a crosssectional study. BMC Public Health. 2015;15(1):1.

66. Alelign T, Degarege A, Erko B. Prevalence and factors associated with undernutrition and anaemia among school children in Durbete Town, northwest Ethiopia. Arch Public Health. 2015;73(1):1.

67. Kelly P, Menzies I, Crane R, Zulu I, Nickols C, Feakins R, et al. Responses of small intestinal architecture and function over time to environmental factors in a tropical population. Am J Trop Med Hyg. 2004;70(4):412-9.

68. Korpe PS, Petri WA. Environmental enteropathy: critical implications of a poorly understood condition. Trends Mol Med. 2012;18(6):328-36

69. Checkley W, Epstein LD, Gilman RH, Cabrera L, Black RE. Effects of acute diarrhea on linear growth in Peruvian children. Am J Epidemiol. 2003;157(2):166-75.

70. Brown J, Cairncross S, Ensink JH. Water, sanitation, hygiene and enteric infections in children. Arch Dis Child. 2013;98(8):629-34.

71. Bhutta ZA, Ahmed T, Black RE, Cousens S, Dewey K, Giugliani E, et al. What works? Interventions for maternal and child undernutrition and survival. Lancet. 2008;371(9610):417-40.

72. Checkley W, Gilman RH, Black RE, Epstein LD, Cabrera L, Sterling CR, et al. Effect of water and sanitation on childhood health in a poor Peruvian periurban community. Lancet. 2004:363(9403):112-8.

73. Lin A, Arnold BF, Afreen S, Goto R, Huda TMN, Haque R, et al. Household environmental conditions are associated with enteropathy and impaired growth in rural Bangladesh. Am J Trop Med Hyg. 2013;89(1):130-7. 
74. Ejemot R, Ehiri J, Meremikwu M, Critchley J, LUBY SP, CURTIS V. Hand washing for preventing Diarrhoea. Commentaries. Int J Epidemiol. 2008; 37(3):470-3.

75. Luby SP, Agboatwalla M, Painter J, Altaf A, Billhimer W, Keswick B, et al. Combining drinking water treatment and hand washing for diarrhoea prevention, a cluster randomised controlled trial. Tropical Med Int Health. 2006;11(4):479-89.

76. Bowen A, Agboatwalla M, Luby S, Tobery T, Ayers T, Hoekstra R. Association between intensive handwashing promotion and child development in Karachi, Pakistan: a cluster randomized controlled trial. Arch Pediatr Adolesc Med. 2012;166(11):1037-44.

77. Ngure FM, Reid BM, Humphrey JH, Mbuya MN, Pelto G, Stoltzfus RJ. Water, sanitation, and hygiene (WASH), environmental enteropathy, nutrition, and early child development: making the links. Ann N Y Acad Sci. 2014;1308(1): 118-28.

78. Adeba A, Garoma S, Fekadu H, Garoma W. Prevalence's of Wasting and its Associated Factors of Children among 6-59 Months Age in Guto Gida District, Oromia Regional State, Ethiopia. J Food Process Technol. 2014;2014

79. Agustina R, Sari TP, Satroamidjojo S, Bovee-Oudenhoven IM, Feskens EJ, Kok FJ. Association of foodhygiene practices and diarrhea prevalence among Indonesian young children from low socioeconomic urban areas. BMC Public Health. 2013;13(1):1.

80. Madhi SA, Cunliffe NA, Steele D, Witte D, Kirsten M, Louw C, et al. Effect of human rotavirus vaccine on severe diarrhea in African infants. N Engl J Med. 2010;362(4):289-98.

\section{Submit your next manuscript to BioMed Central and we will help you at every step:}

- We accept pre-submission inquiries

- Our selector tool helps you to find the most relevant journal

- We provide round the clock customer support

- Convenient online submission

- Thorough peer review

- Inclusion in PubMed and all major indexing services

- Maximum visibility for your research

Submit your manuscript at www.biomedcentral.com/submit 